Int. Archs Allergy appl. Immun. 1983;72:I-IV

\title{
Contents, Vol. 72, 1983
}

\section{Vol. 72, 1983}

International Archives

of Allergy and Applied

Immunology

Founded 1950 by D. Harley, P. Kallós, W. Löffler and F.W. Wittich Continued by E.A. Brown

(1952-1954), W. Kaufman (1955-1967), F. Hahn (1961-1972) and H.C. Goodman (1963-1975)

Editors-in-Chief

R.R.A. Coombs, Cambridge L.Å. Hanson, Göteborg P. Kallós, Helsingborg F. Milgrom,

Buffalo, N.Y. Z. Trnka, Basel G.B. West, Epsom

Liaison Editors

J.M. Cruse, Jackson, Miss. L.M. Schwartz, East Orange, N.J.

Contributing Editors

C.J. Abeyounis, Buffalo, N.Y.

N.F. Adkinson, Jr., Baltimore, Md.

B. Albini, Buffalo, N.Y.

G. Andres, Buffalo, N.Y.

E.L. Becker, Farmington, Conn.

L. Belin, Göteborg

W.E. Brocklehurst, Windlesham

A. Capron, Lille

A. Cerletti, Basel

C.G. Cochrane, La Jolla, Calif.

B. Diamant, Copenhagen

P. Dukor, Basel

L. Edebo, Göteborg

W.P. Faulk, Charleston, S.C.

P.G.H. Gell, Birmingham

I. Glazer, Tel Aviv

R.A. Good, Oklahoma City, Okla.

M. Hess, Bern

L. Hudson, Beckenham

H. Isliker, Lausanne

S.G.O. Johansson, Stockholm

E.A. Kabat, New York, N.Y.

K. Kano, Tokyo

W. Müller-Ruchholtz, Kiel

F. Ørskov, Copenhagen

Ö. Ouchterlony, Göteborg

Z. Ovary, New York, N.Y. 
P. Perlmann, Stockholm

E. Pick, Tel Aviv

M. Plaut, Baltimore, Md. R.E. Reisman, Buffalo, N.Y.

G. Riethmüller, München

M. Roitt, London

K. Rother, Heidelberg

G. Sandberg, Stockholm

H.D. Schlumberger, Wuppertal

K.H. Schulz, Hamburg

A. Sehon, Winnipeg

O. Strannegård, Göteborg

A. Szentivanyi, Tampa, Fla.

T.B. Tomasi, Jr., Albuquerque, N. Mex.

O. Tönder, Bergen

G. Torrigiani, Geneve

J.L. Turk, London

E.R. Unanue, Boston, Mass.

B.H. Waksman, New York, N.Y.

A.L. de Week, Bern

G. Wick, Innsbruck

$\mathrm{mm}$

Contents Vol. 72,1983

No. 1

Original Paper

Facilitation of cAMP Increments during ADCC Mediated by

Monocytes Pretreated with cAMP-Elevating Agents

Herlin, T.; Kragballe, K 1

Suppression of IgE Antibody Response by Irradiated Reticulum Cell Sarcoma Cells in SJL Mice

Watanabe, N.; Ovary, Z 6

Circulating Immune Complexes and $\mathrm{Cl}$ Activation in Patients

with Rapidly Progressive Glomerulonephritis, before and

after Treatment with Immunosuppression and Plasma Exchange

Sjöholm, A.G.; Brun, C; Larsen, S.; Thysell, H 9

Kinetics of Specific IgE Antibody and Total IgE Responses in

Mice: The Effect of Immunosuppressive Treatment

Wyczólkowska, J.; Brzezińska-Blaszczyk, E.; Masliński, C. 16 Inhibition of Cytotoxic T

Lymphocytes by a Schistosome-

Derived Inhibitory Factor Is Independent of an Inhibition

of the Production of Interleukin 2

Mazingue, C; Dessaint, J.P.; Schmitt-Verhulst, A.M.;

Cerottini, J.C.; Capron, A 22

Inhibition of Passive Localized Experimental Allergic Encepha-

lomyelitis by Interferon

Abreu, S.L.; Tondreau, J.; Levine, S.; Sowinski, R 30

Immediate Hypersensitivity Reaction to ß-Lactoglobulin in the 
Epithelium Lining the Colon of Guinea Pigs Fed Cows'

Milk

Cuthbert, A.W.; McLaughlan, P.; Coombs, R.R.A 34

Effect of Sulfhydryl-Reactive ATPase Inhibitors upon Mast

Cell and Basophil Activation

Magro, A.M.; Cragoe, E.J., Jr.; Hurtado, I.; Rudofsky,

U.H 41

Enhancement of Granulocyte Oxidative Metabolism in Sera

from Patients with C2 Deficiency and Systemic Lupus erythematosus

Rhee, M.S.; Rynes, R.I.; Pickering, R.J.; Borkowski, M.A.;

Charbonneau, T.T.; Eastlund, D.T.; Meuwissen, H.J. ... 46 Sensitivity of Passive Cutaneous

Anaphylaxis in Rats. I. Inverse Relationship between PCA Sensitivity and Amount of

IgE Present on Mast Cells

Watanabe, N.; Kobayashi, A 53

Sensitizing Ability of Derivatives of Picryl Chloride after Expo

sure of Mice on the Skin and in the Lung

Enander, I.; Ahlstedt, S.; Nygren, H.; Björkstén, B 59

Depression or Enhancement of Skin Reactivity by Inflammatory Processes in the Guinea Pig

Bruynzeel, D.P.; Blomberg-van der Flier, M. von; Ketel,

W.G. van; Scheper, R.J 67

Immune Responses in Rats Sensitized with Aerosolized Antigen. Antibody Formation,

Lymphoblastic Responses and Mast Cell and Mucous Cell Development Related to Bronchial

Reactivity Ahlstedt, S.; Smedegård, G.; Nygren, H.; Björkstén, B. ... 71

Grass Conjuvac ${ }^{\circledR}$. I. Immunogenicity in Rabbits, Guinea Pigs

and Rats

Taylor, W.A.; Francis, D.H 79

Short Communications

Production of Monoclonal Antibodies against Wheat Flour Components

Theobald, K.; Bohn, A.; Thiel, H.; Rasche, B.; Ulmer,

W.T.;König, W 84

Local and Systemic Immune Responses to Intestinally Pre

sented Antigen

Nicklin, S.; Miller, K 87

Effects of Novel Lipoxygenase Products on Migration of Eosin-ophils and Neutrophils in vitro

Udén, A.-M.; Palmblad, J.; Lindgren, J.-Å.; Malmsten, C. . 91

Book Reviews

94

No. 2

Original Paper

The Atopic Dog Model: Report of an Attempt to Establish a Colony

Schwartzman, R.M.; Massicot, J.G; Sogn, D.D.; Cohen,

S.G 97

Inhibitory Effect of Nifedipine and Cromolyn Sodium on Skin

Reactions and 45Ca Uptake and Histamine Release in Rat

Mast Cells Induced by Various Stimulating Agents

Tanizaki, Y.; Akagi, K.; Lee, K.N.; Townley, R.G 102 
Contents

HI

Macrophages in Efferent Lymph of Sheep and Their Role in Lectin-Induced Lymphocyte Blastogenesis

De Martini, J.C.; Fiscus, S.A.; Pearson, L.D 110

Presence of Basophils in PHA-Reacted Skin Sites of Mice. An

Electron Microscopic Study

Hurtado, I.; Urbina, C 116

IgA Isotype Restriction in the Mucosal but Not in the Extramu-

cosal Immune Response after Oral Immunizations with

Cholera Toxin or Cholera B Subunit

Lycke, N; Lindholm, L.; Holmgren, J

Circulating Immune Complexes and Their Possible Relevance

to Other Immunological Parameters in Guatemalan Oncho-

cerciasis

Kawabata, M.; Izui, S.; Anan, S.; Kondo, S.; Fukumoto, S.;

Flores, G.Z.; Kobayakawa, T 128

New Preparative Schedule and Further Characterization of a

Thymocyte Specific Growth Factor from Calf Thymus

Söder, O.; Ernström, U 134

Search for Thymocyte Growth-Stimulating Activity in Extracts of Different Tissues and among Established Growth Factors

and Thymic Maturation Hormones

Söder, O.; Ernström, U 139

Cytotoxicity of Temporarily Adherent Human Mononuclear

Blood Cells in Monocyte Monolayers

Eggen, B.M 143

Immune Response to Trichomonas vaginalis. IV. Immunochemical and Immunobiological Analyses of T. vaginalis

antigen

Yano, A.; Yui, K.; Aosai, F.; Kojima, S.; Kawana, T.;

Ovary, Z 150

The Optimum Conditions for Antibody Production in vitro by

Peyer's Patch Lymphocytes and a Comparison between

Total Immunoglobulins and Antigen(TNP)-Specific Antibody Synthesis following Mitogen

Stimulation

Layton, G.T.; Smithyman, A.M 158

Susceptibility of Two Colonies of Wistar Rats to Inflammation, with Particular Reference to Delayed Hypersensitivity

Brito, F.B. de; Hanahoe, T.H.P 164

T Cell Mediated Polyclonal B Cell Activation Induced by Cell-Bound Fetal Calf Serum

Cowdery, J.S., Jr.; Steinberg, A.D 170

Short Communications

Stimulating Effect of Mercuric Chloride and Nickel Sulfate on

DNA Synthesis of Thymocytes and Peripheral Lymphoid 
Cells from Newborn Guinea Pigs

Nordlind, K 177

Rheumatoid-Like Synovitis in Rabbits by Intra-Articular Ad

ministration of $\mathrm{o}^{1 / 8} / \mathrm{M}$-Macroglobulin $\cdot$ Trypsin Complexes and

Alkylamine-Treatedo $1 / 8-$ Macroglobulin

Borth, W.; Susani, M 180

Reverse Enzyme Immunoassay for the Determination of Lolium perenne IgE Antibodies Cuevas, M.; Moneo, I.; Ureña, V.; Dominguez, J.; Bootello, A. 184

Human Tonsillar Mast Cells. Characteristics of Histamine Se

cretion and Methods of Dispersion

Church, M.K.; Mageed, R.A.K.; Holgate, S.T 188

Book Reviews 191

No. 3

Original Paper

Comparison of Iodinated Antigens of Metastatic and Non-Met-

astatic Mammary Adenocarcinoma Cells

Abbas, M.K.; Yoo, T.-J 193

Homocytotropic and Heterocytotropic Activity of Mouse IgGl

Antibodies

Mota, I.; Perini, A 199

Effect of Purified Excreted Factor from Leishmania brasiliensis

on Macrophage Activity

Rodriguez, N.; Hernandez, A.G.; Merino, F 206

Effect of Chemotherapy and Reinfection on IgE-Containing and IgG-Containing Circulating Immune Complexes, Serum IgE and IgE Antibodies in Patients Chronically Infected with

Schistosoma mansoni and Schistosoma haema-tobium

Feldmeier, H.; Stevens, W.J.; Bridts, C.H.; Daffalla, A.A.;

Büttner,D.W 211

Allergens of Schistosoma mansoni. I. Comparison of the IgE

Response in Human and Experimental Infections towards

Characterized Allergens from Adult Worm Products

Pierce, R.J.; Verwaerde, C; Damonneville, M.; LePresle,

T.;Capron, A 219

Immunomodulating Effects of 13-cis Retinoic Acid on the IgG

and IgM Response of BALB/c Mice

Barnett,J.B 227

A Comparison of Histamine Secretion from Isolated Peritoneal

Mast Cells of the Mouse and Rat

Barrett, K.E.; Pearce, F.L 234

Fluorescein Isothiocyanate as a Cell Marker for Tracing Lymphocyte Circulation in Sheep

Schnorr, K.L.; Pearson, L.D.; Knisley, K.A.; DeMartini,

J.C 239

Development of Monoclonal Mouse Antibodies Specific for

Allergenic Components in Ryegrass (Lolium perenne) Pollen

Smart, I.J.; Heddle, R.J.; Zola, H.; Bradley, J243 
Deficiency of IgG Subclasses in Mothers of Infants with Group B Streptococcal Septicemia Oxelius, V.-A.; Linden, V.; Christensen, K.K.; Christensen, P. 249

Regulation of the Development of Plaque-Forming Cells to Bromelain-Treated Syngeneic Mouse Erythrocytes in Bone Marrow Cell Cultures

Garzelli, G; Forlani, A.; Lombardi, S.; Colizzi, V.; Campa, M.; Falcone, G 253

Comparison of the Specific IgM and IgG Antibody Response in

Humans Induced by Antigen (Tetanus Toxoid) or a Poly

clonal Activator (EBV) in vitro

Kozbor, D.; Roder, J.C 260

Monoclonal Hybridoma Antibodies against Human IgE and Their Use in a Rapid and Sensitive Enzyme Immunoassay for the Semiquantitative Assessment of Total IgE Levels in Human Blood Chandler, H.M.; Coulter, A.R.; Healey, K.; Kornitschuk,

M.; MacGregor, A.; Hurrell, J.G.R 267

Granular and Globular Acid $\alpha$-Naphthyl-Acetate-Esterase

Staining Pattern of Resting and Mitogen-Activated Murine

Lymphocytes

Treves, S.; Ali-Khan, Z 273

IV

Contents

Comparison of Antigens in the Rat MHC That Act as CML Determinants Liebert, M.; Kunz, H.W.; Gill, T.J., III; Cramer, D.V. . . 279

Short Communications

Histamine Releasers and Rat Mast Cells

West, G.B 284

Adjuvancy of Cremophor $\mathrm{El}^{\circ}$ in Rodents

Descotes, J.; Tachon, P.; Laschi-Locquerie, A.; Evreux,

J.C 287

No. 4

Original Paper

Action of 3-Isobutyl-1-Methylxanthine and Prostaglandins D2

and Ei on Histamine Release from Rat and Guinea Pig

Mast Cells

Ennis, M.; Robinson, C; Dollery, C.T 289

Studies on the Antigenic Composition of Aqueous Cotton Dust

Extracts

O’Neil, C.E.; Reed, M.A.; Aukrust, L.; Butcher, B.T 294

Hapten-Specific Help Mediated by an Anti-ABA T Cell Line

Kojima, A.; Thomas, W.R.; Mottram, P.L.; Miller,

J.F.A.P299

Decreased Sensitivity and Response of Isolated Tracheal Mus

cle to Methacholine and Histamine without Changing the

Activity of Pulmonary Muscarinic Receptors in the Egg

Albumin-Sensitized Guinea Pig

Cheng, J.B.; Townley, R.G 303 
A Unique Substance from the Granary Weevil: Nonspecific Immunoglobulin Binding Substance Mitsuhashi, M.; Tamura, H.; Morikawa, A.; Kuroume, T. . 310

Inhibitory Effect of Human Interferons on Lymphocyte Prolif

eration Induced by Phytomitogens in Cynomolgus Mon

keys (Macacafascicularis)

Tatsumi, M.; Kohase, M.; Yamazaki, S 316

Effects in Mice of Rat Bromelain-Treated RBC and Lipopoly-

saccharide on Autoantibody Production against Bromelain-

Treated Isologous RBC

Cox, K.O.; Ramos, T.; Cox, J.; Samcewicz, B 325

The Reactivities of Bauhinia pupurea and Lens culinaris Lec-

tins to Mouse B Lymphocytes and Their Subsets

Hishinuma, A.; Imai, Y.; Nakano, T.; Osawa, T 330

Heterogeneity of Human Peripheral Blood Eosinophils: Variability in Cell Density and

Cytotoxic Ability in Relation to the Level and the Origin of Hypereosinophilia Prin, L.; Capron,

M.; Tonnel, A.-B.; Bletry, O.; Capron, A. 336

Genetic Dependence of IgE Antibody Production in Mice

Infected with the Nematode Nippostrongylus brasiliensis.

I. Modulation of the IgE Antibody Response in vivo by

Serum Factors

Pfeiffer, P.; König, W.; Bohn, A 347

Short Communications

Genetic Susceptibility of Rats to Some Forms of Delayed

Hypersensitivity

Brito, F.B. de; Hanahoe, T.H.P 356

Adjuvant Effects oft, $\kappa$, and $\lambda$ Carrageenans on Antibody Production in BALB/c Mice

Mancino, D.; Minucci, M 359

C5a-Induced Histamine Release. Species Specificity

Regal, J.F.; Hardy, T.M.; Casey, F.B.; Chakrin, L.W. ... 362 Distribution of $7 / 8$ Dextran in Two

Colonies of Wistar Rats

after Intravenous Injection

Hanahoe, T.H.P.; Wright, J.D366

Allergic Reactivity and Helminthic Infection in Amerindians of

the Amazon Basin

Lynch, N.R.; Lopez, R.; Istúriz, G; Tenías-Salazar, E. . . . 369 Changes of Beta-Adrenergic

Receptor Number and Catechol-

amine-Sensitive Adenylate Cyclase in Guinea Pig Lung

after Inhalation of Histamine Aerosol

Mita, H.; Yui, Y.; Shida, T 373

Book Reviews 377

News Items 378

Author Index 379

S. Karger $\cdot$ Medical and Scientific Publishers $\cdot$ Basel

- München · Pans · London · New York · Tokyo · Sydney 
Drug Dosage

The authors and the publisher have exerted every effort to ensure that drug selection and dosage set forth in this text are in accord with current recommendations and practice at the time of publication. However, in view of ongoing research, changes in government regulations, and the constant flow of information relating to drug therapy and drug reactions, the reader is urged to check the package insert for each drug for any change in indications and dosage and for added warnings and precautions. This is particularly important when the recommended agent is a new and/or infrequently employed drug.

All rights reserved.

No part of this publication may be translated into other languages, reproduced or utilized in any form or by any means, electronic or mechanical, including photocopying, recording, microcopying, or by any information storage and retrieval system, without permission in writing from the publisher or, in the case of photocopying, direct payment of a specified fee to the Copyright Clearance Center (see 'Information for Readers and Subscribers').

(C) Copyright 1983 by S. Karger AG, P.O. Box, CH-4009 Basel (Switzerland) Printed in Switzerland by Buchdruckerei Basler-Zeitung AG, Basel 